Lucrările Seminarului Geografic Dimitrie Cantemir

Vol. 45, October 2017, pp. 125-150

http://dx.doi.org/10.15551/lsgdc.v45i0.10

\title{
Are the bearers of Carp name the descendants of the ancient tribe of the carpi?
}

\section{Ionel Boamfă ${ }^{1}$}

${ }^{1}$ Alexandru Ioan Cuza University of Iasi, Romania.

To cite this article: Boamfă, I. (2017). Are the bearers of Carp name the descendants of the ancient tribe of the carpi?. Lucrările Seminarului Geografic Dimitrie Cantemir, Vol. 45, pp. 125150. DOI: $10.15551 /$ lsgdc.v45i0.10

To link to this article: http://dx.doi.org/10.15551/lsgdc.v45i0.10 


\title{
ARE THE BEARERS OF CARP NAME THE DESCENDANTS OF THE ANCIENT TRIBE OF THE CARPI?
}

\author{
Ionel Boamfă 1
}

\begin{abstract}
Following the inventory of onomastic material (largely anthroponymic, during the XIV-XXI centuries and, to a lesser extent, the toponimy of XVIII-XXI centuries), taking into account some historical, religious, cultural, ethnographic arguments, we try to answer to the question whether the bearers of the Carp name are (or not?) the descendants of the ancient tribe of the Carpi.
\end{abstract}

Keywords: Carp name, the Carpi, historical Moldavia, Thracians-Dacians, Romanization of Thraco-Dacians, anthroponyms, toponyms;

\section{Introduction}

The idea from which we started in our scientific approach is given by the possible connection between the Carpi and the anthroponym Carp (mainly located in historical Moldavia - in a broad sense, including the present historical-geographic regions of Moldavia, Bucovina and Basarabia and, according to the data from the last century, even in Transnistria).

The Carpi were one of the tribes (probably Thraco-Dacians) who inhabited the eastern part of the Dacian Kingdom (probably east of the Eastern Carpathians) in the last part of antiquity. About their role (especially related to the conflicts with the Roman Empire, in the $2^{\text {nd }}$ to $4^{\text {th }}$ centuries AD), one can read a work ${ }^{2}$ with documented information. The spread of the Carpi tribe, mentioned before the Kingdom of Dacia (from the $5^{\text {th }}$ to the $2^{\text {nd }}$ centuries BC), is highlighted below in Figures 1-7. After the long period in which they are remembered, the Carpi survived, as a Thraco-Dacian tribe, almost a millennium (from the $5^{\text {th }}$ century BC until the $4^{\text {th }}$ century AD). From the documentary and / or archaeological information, the Carpi disappear from the mentions in the $4^{\text {th }}$ century (more precisely, from AD 318 ), the explanation for this disappearance being, according to the experts, related to the significant military losses during the conflicts with the Romans and the displacements within the Empire, made by the Roman emperors since 270 AD.

We are inclined towards another cause of the alleged "disappearance" of the Carpi. In 313, the Emperor Constantine the Great promulgated the famous Edict from Mediolanum / Milan, whereby Christianity was recognized as an official religion in the Roman Empire. As the emperor was of the Thraco-Roman origin (born at Naissus / Niš), it was possible to have

\footnotetext{
${ }^{1}$ Lecturer PhD, CUGUAT-TIGRIS, Department of Geography, Faculty of Geography and Geology, „Alexandru Ioan Cuza” University of Iași.

${ }^{2}$ Petrescu-Dîmbovița M., Daicoviciu Hadrian, Bârzu Ligia, Teodor Dan Gh., Preda Florentina (1995)

- Istoria României de la începuturi până în secolul al VIII-lea, Editura Didactică și Pedagogică R.A., București
} 
called the great Dacian priests and to propose that he renounce the cult of Zamolxis and move to the new confession. Apparently, if not all, an important part of the great priests of the cult of Zamolxis accepted the proposal of the Emperor Constantine, followed by a significant number of Thraco-Dacians. With this passage, through the adoption of Christianity, the Thraco-Daco-Romans also adopted the Latin language, but also the term romanus = Roman, which became, in the later dialects of the Romanian, român/rumân/ar(u)mân/*rumon/rumăr = Romanian .

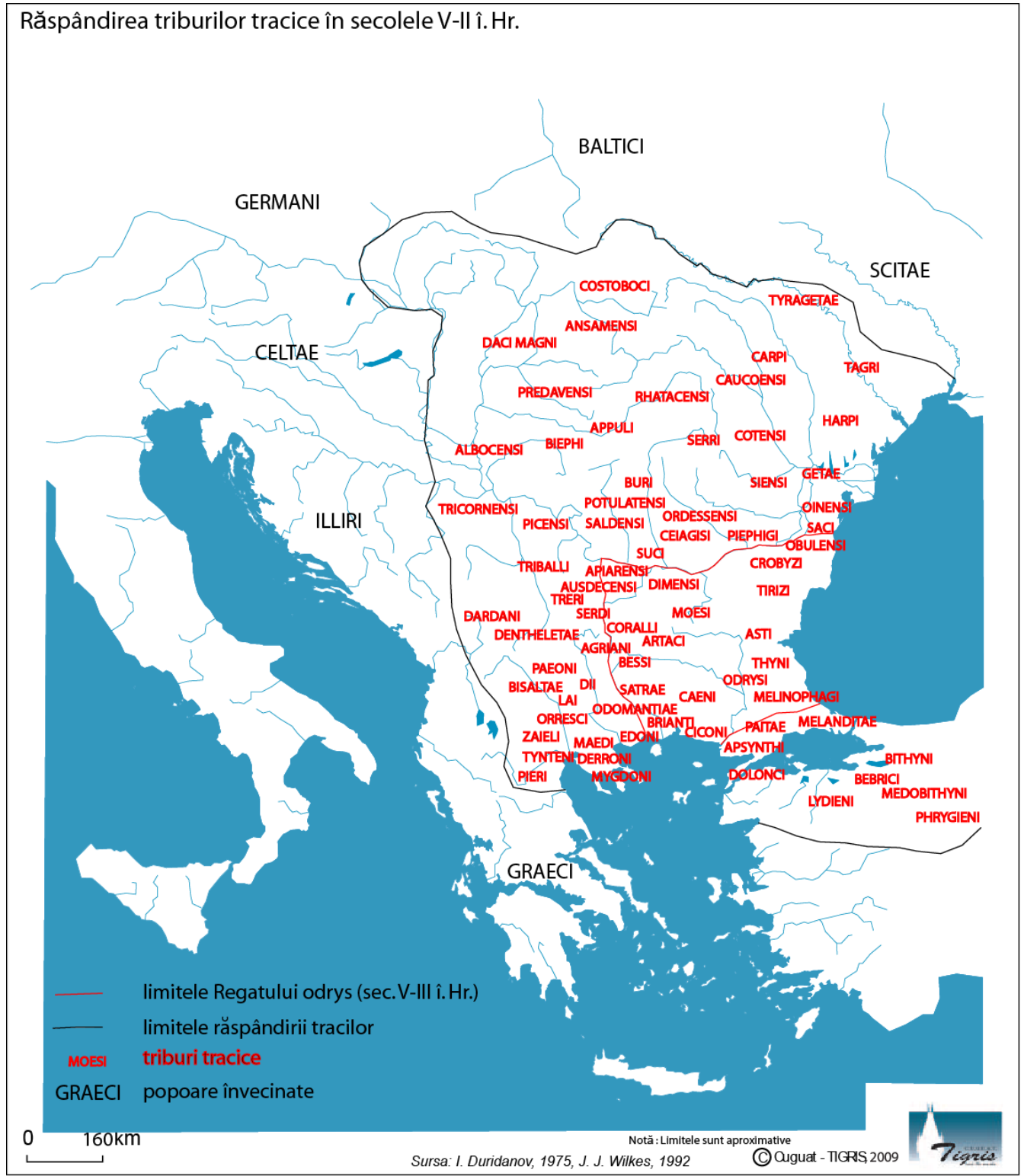

Figure 1 - The position of of the Thracian tribes in V-II B.C 
This fact is reinforced by the presence in the Christian terminology of the Romanian language of numerous terms of Latin origin $($ cruce $=$ cross, creștin $=$ Christian, biserică/băsearică $=$ church, preot $/$ preftu $=$ priest, botez $=$ baptism, Dumnezeu/Dumnidzălu $=$ God, Paște $=$ Easter , Crăciun $=$ Christmas, cuminecare $=$ communion, păresimi $=40$-day period before the Easter etc.), numerous anthroponims of Constantinopolitan origin (related to the old Christian Church of the Eastern Roman Empire, named in the modern times "Byzantine"): Ioan = John, Nicolae $=$ Nicholas, Andrei $=$ Andrew, Gheorghie $=$ George, Vasilie $=$ Basil, Dumitru $=$ Demetrius and others and the presence in two of the important prayers of Christians - Tatăl nostru $=$ Our Father and Crezul $=$ the Creed - of over $80 \%$ terms of Latin origin (attested in the Orthodox variants of these religious texts).

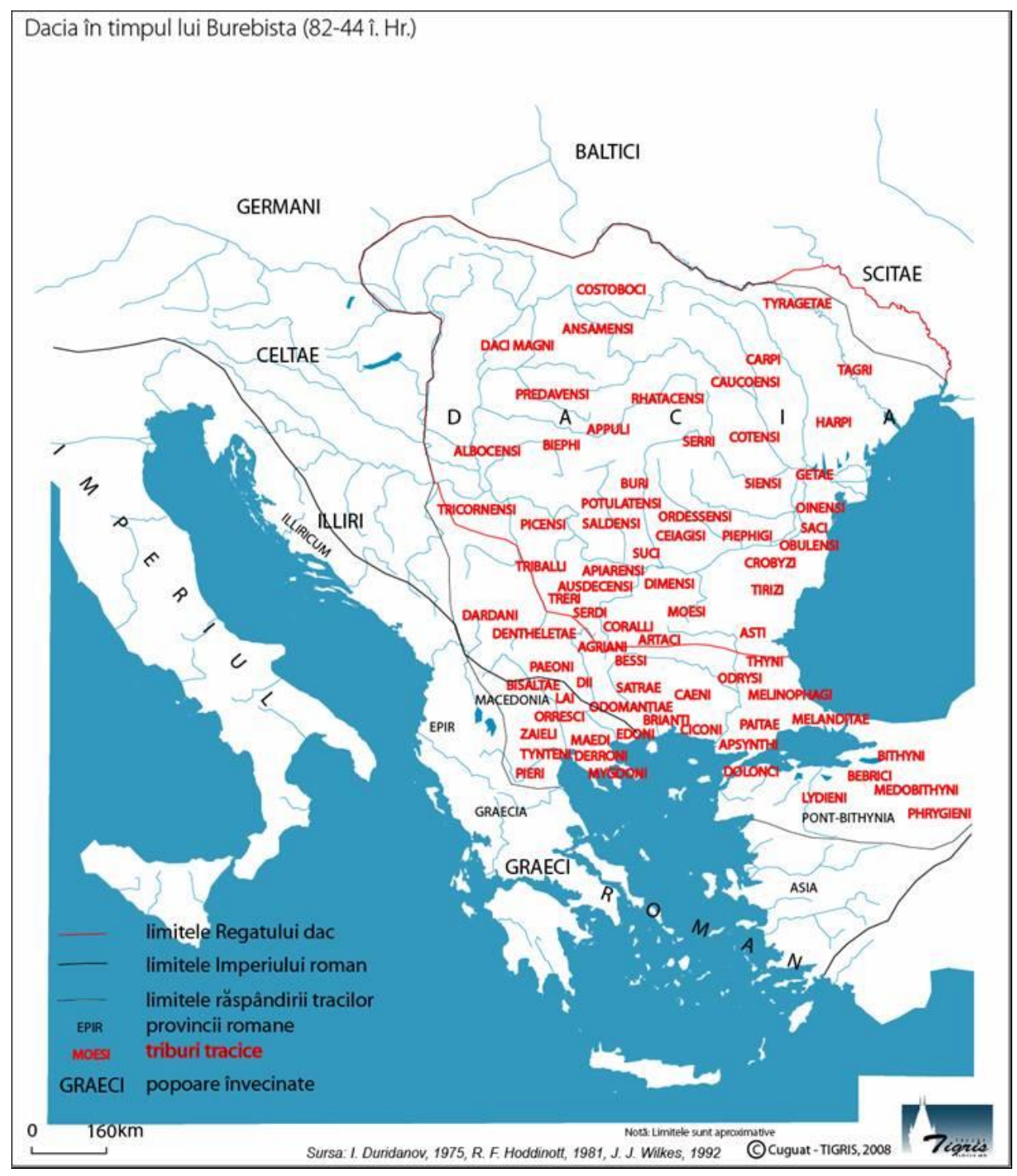

Figure 2 - Dacia during Burebista (82-441 B.C) 
It adds the tradition of the Thraco-Daco-Roman Christianization by Saint Apostle Andrew (preserved by the popular name given to the month after St. Andrew's Day: November 30 - December: Indrea / Undrea - to the Daco-Romanians, Andreu to the Aromanians) and the extension of popular forms for the Constantinopolitan calendar names: Ziane / Sânziane, Nicoară / Nicăruş / Sânnicoară, Îndrei / Indrei, Georzu / Giurgi / Sângeorz, Văsâi / Sânvăsii, Medrea / Sâmedru / Sumedru, Sântoader, etc, for the official forms Ioan, Nicolae, Andrei, Gheorghie, Vasilie, Dimitrie, Teodor and so on.

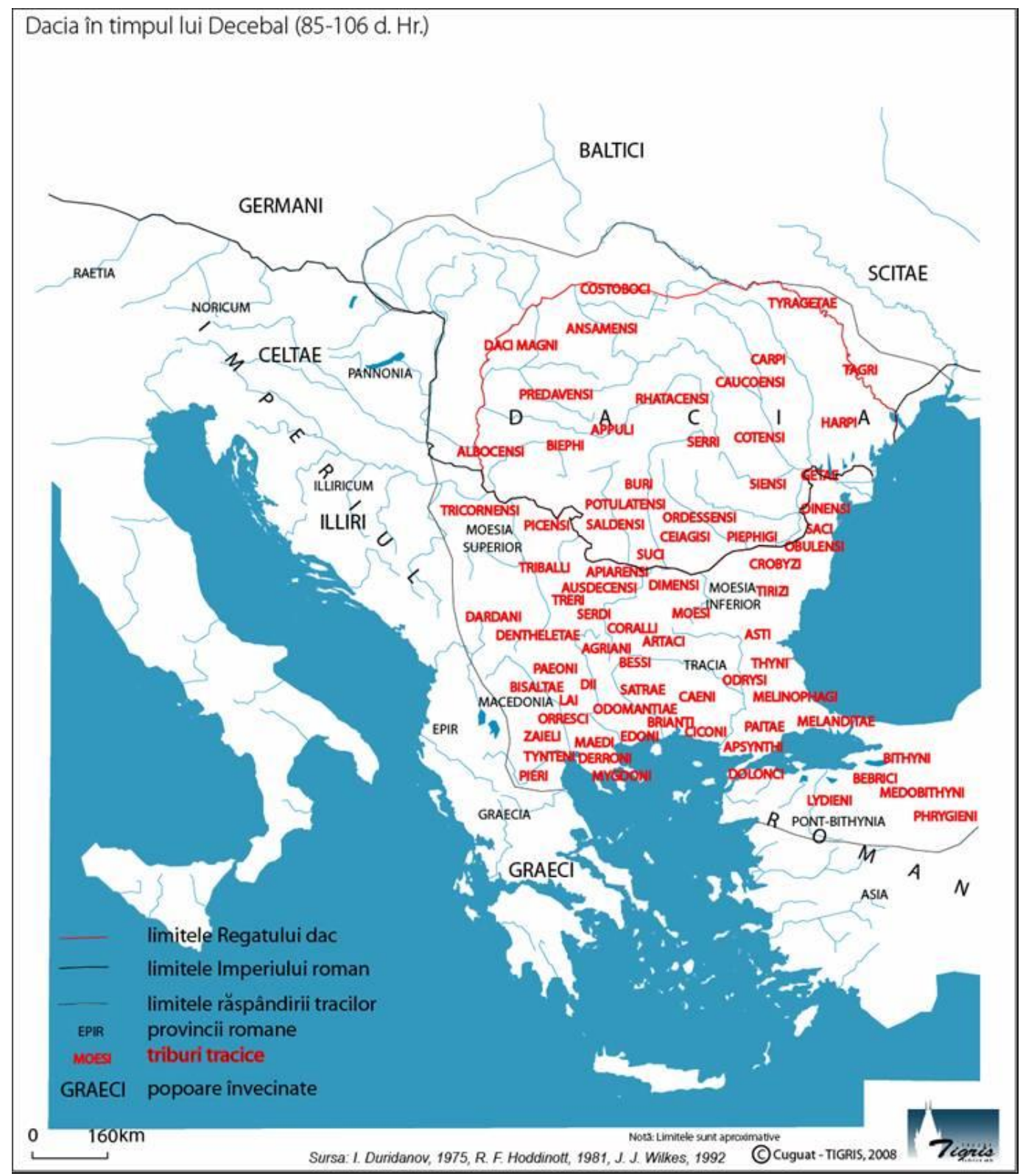

Figure 3 -Dacia during Decebal (85 - 106 A.D) 
As the "disappearance" of the Carpi from the documentary testimonies occurred a few years after the Mediolanum Edict, we suspect that, like the other Thraco-Dacians (Romanized or not), the Carpi have given up attacking the Empire and even declaring it ... Carpi, but, as in the case of the other pre-Christian traditions preserved after Christianisation ( $a$ da ortul popii-tradition related to the passage in the "other world" of Hades, the cult of the "Thracian Knight" became the image of St. George killing the dragon and kept as a flag of battle of the army from the Middle Ages to the present, etc.), the ancestors of today's Moldovans have considered that they can keep their name as a patronymic. It survived (until today, even) first as baptismal name, and from the final phase of the Middle Ages (17 $-18^{\text {th }}$ centuries) it became a surname / family name.

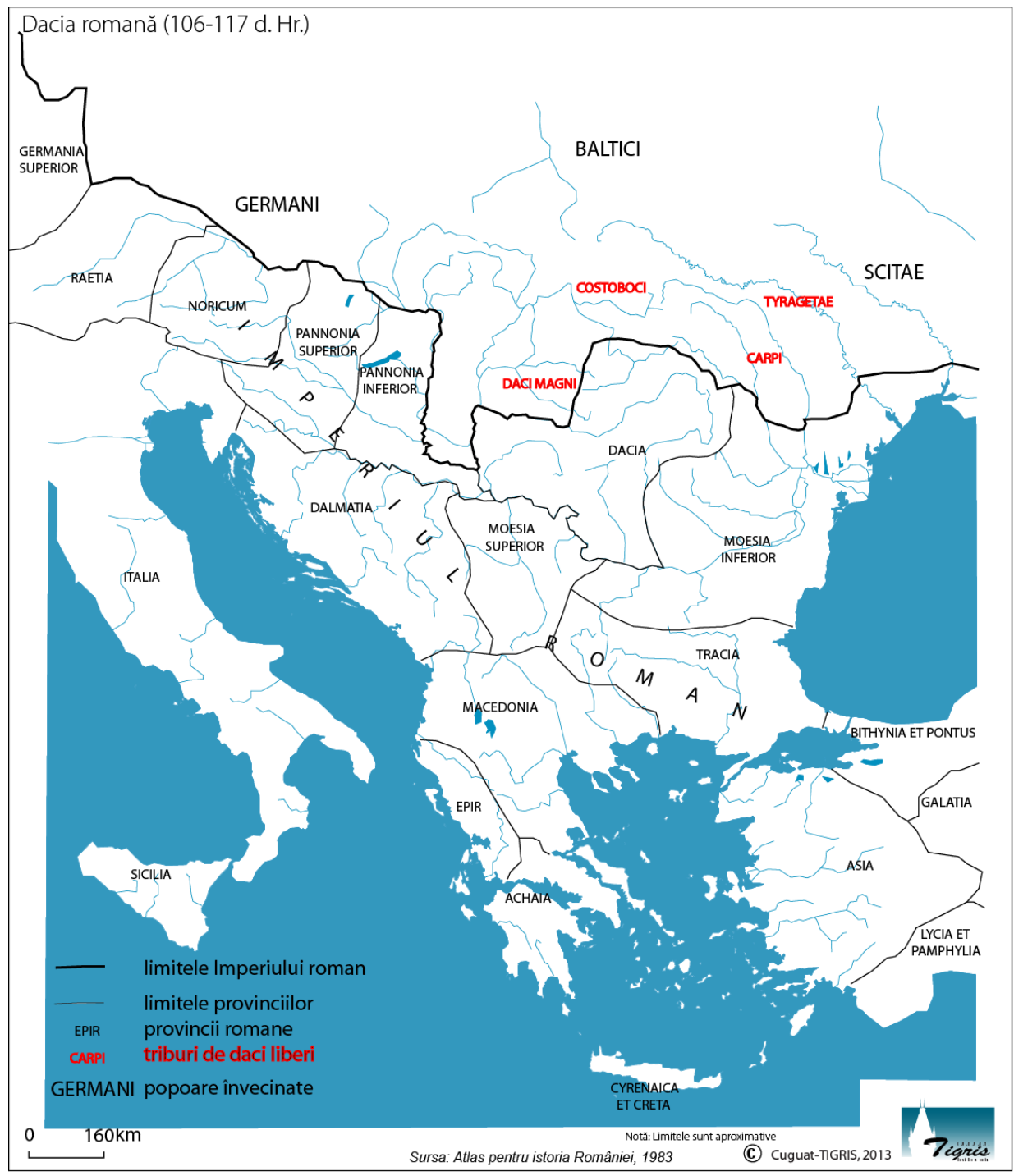

Figure 4 - The Roman Dacia (106 - 117 A.D) 


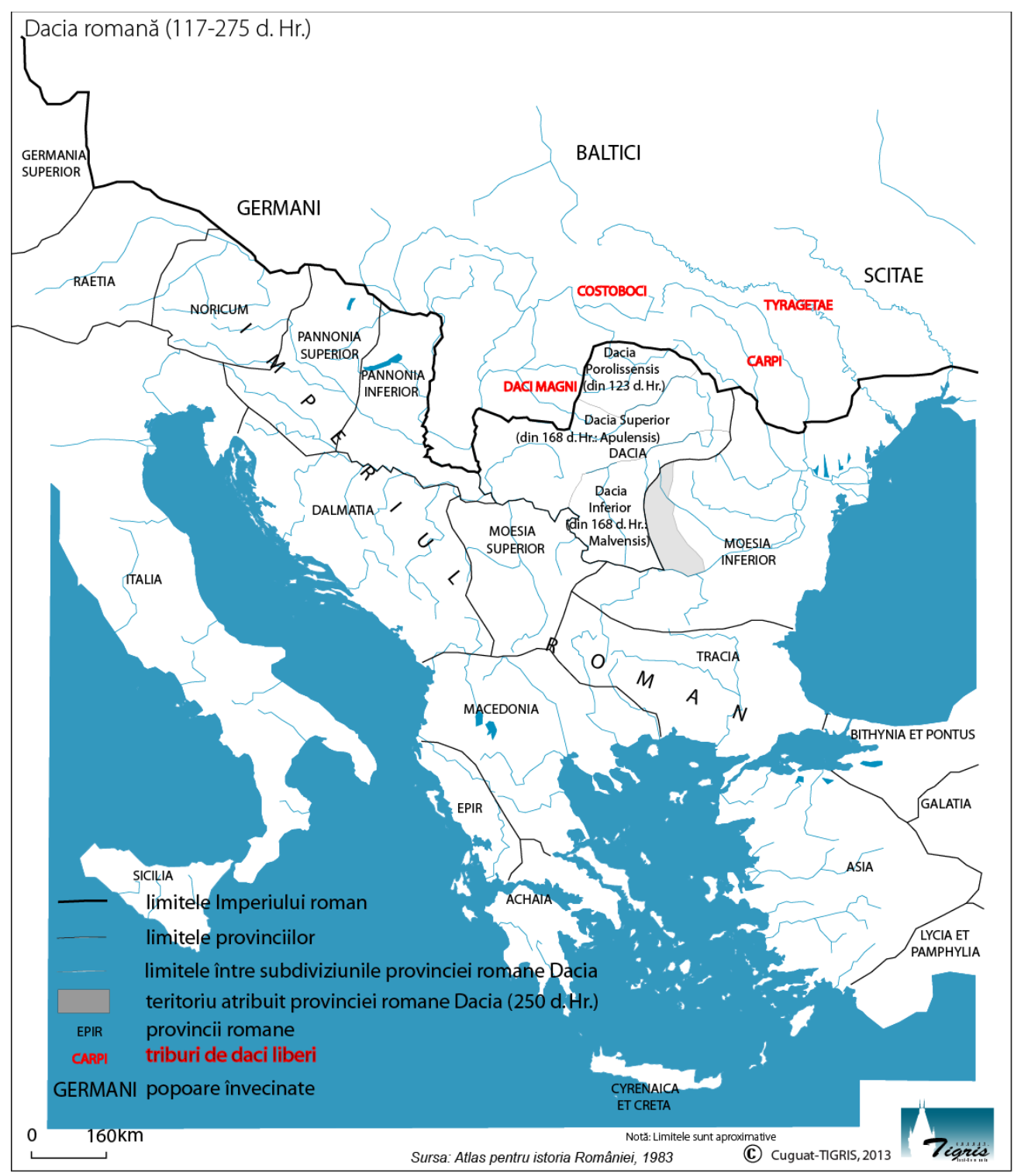

Figure 5 - The Roman Dacia (117-275 A.D)

The preservation of this name by the Romanized and Christianized Carpi, remaining on the territory of the future Moldavia, is also explained by the continuity of the politicaladministrative and religious life east of the Carpathians. Thus, the old Petrodava (in translation: Cetatea Piatra = the Stone Citadel) reappears in medieval documents under the name Piatra lui Crăciun (Crăciun probably being a local lord who joined his little political formation in the voivodship of Moldavia), then Piatra (and from the Union of Principalities 
until today - Piatra-Neamtr). To the east of Siret, the old Dacian settlement Paloda ${ }^{3}$ (with a native name, similar to the Latin term paludem) became, under the influence of the Slavs, Bârlad, the political center of Tara Berladnicilor $=$ the Country of the Berladnici (documented in the XI-XIII centuries) and integrated in the same medieval Moldavia.

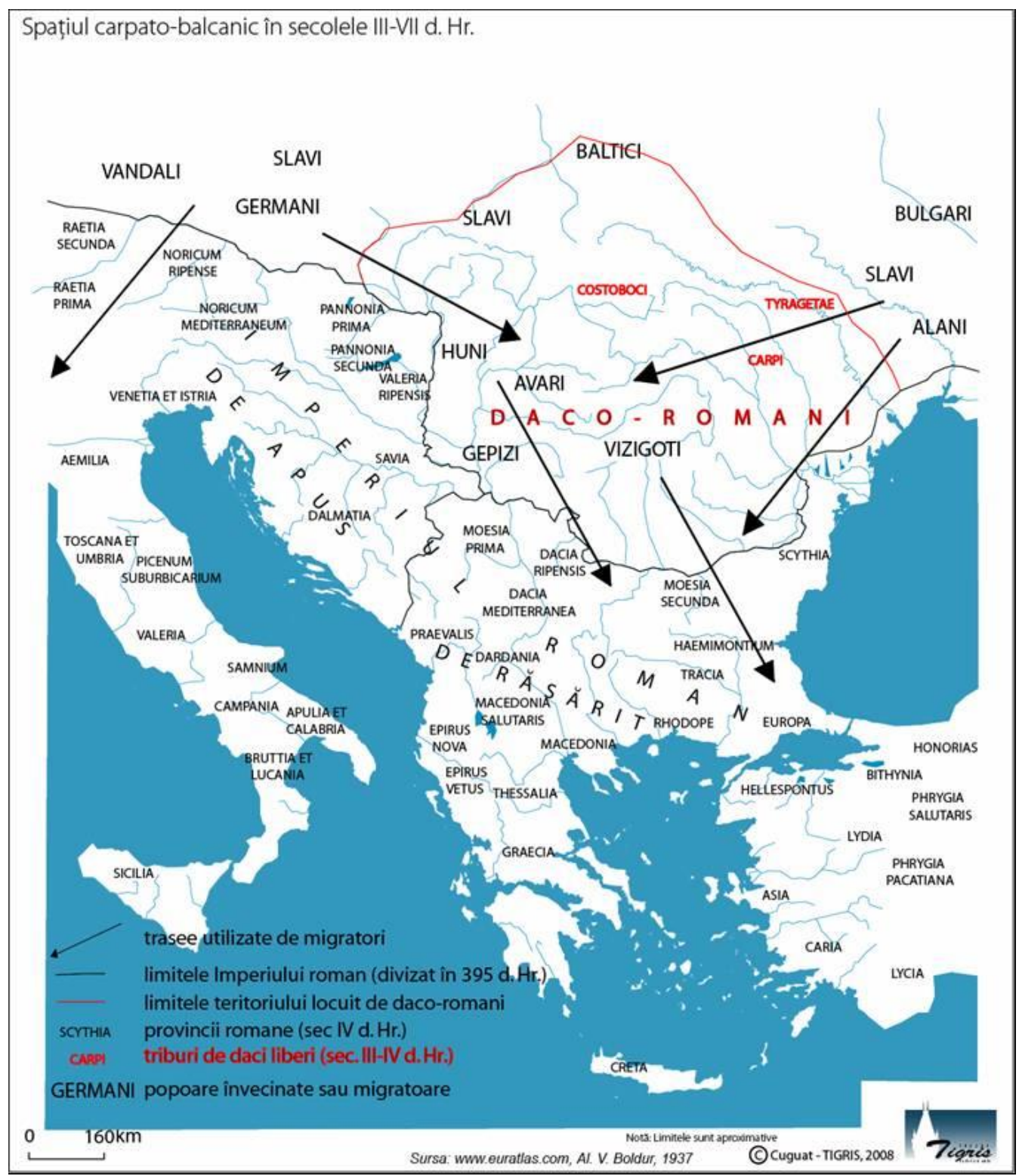

Figure 6 - The Carpathian-Balkan space between III-VII A.D

${ }^{3}$ With the sense of a place with excess of humidity, the course of the Bârlad River (from which, by metonymy, the city will have taken its name, even since - water and settlement - will have been called Paloda) having until today, this feature. 
On the other hand, probably, as we argued, on another occasion ${ }^{4}$, the holy mountain of the Dacians, Kogaionon, would have been Ceahlăul, transformed after the Christianization of the local population into the holy mountain of the Moldovan Romanians, as already, Dimitrie Cantemir described it three centuries ago (1716).

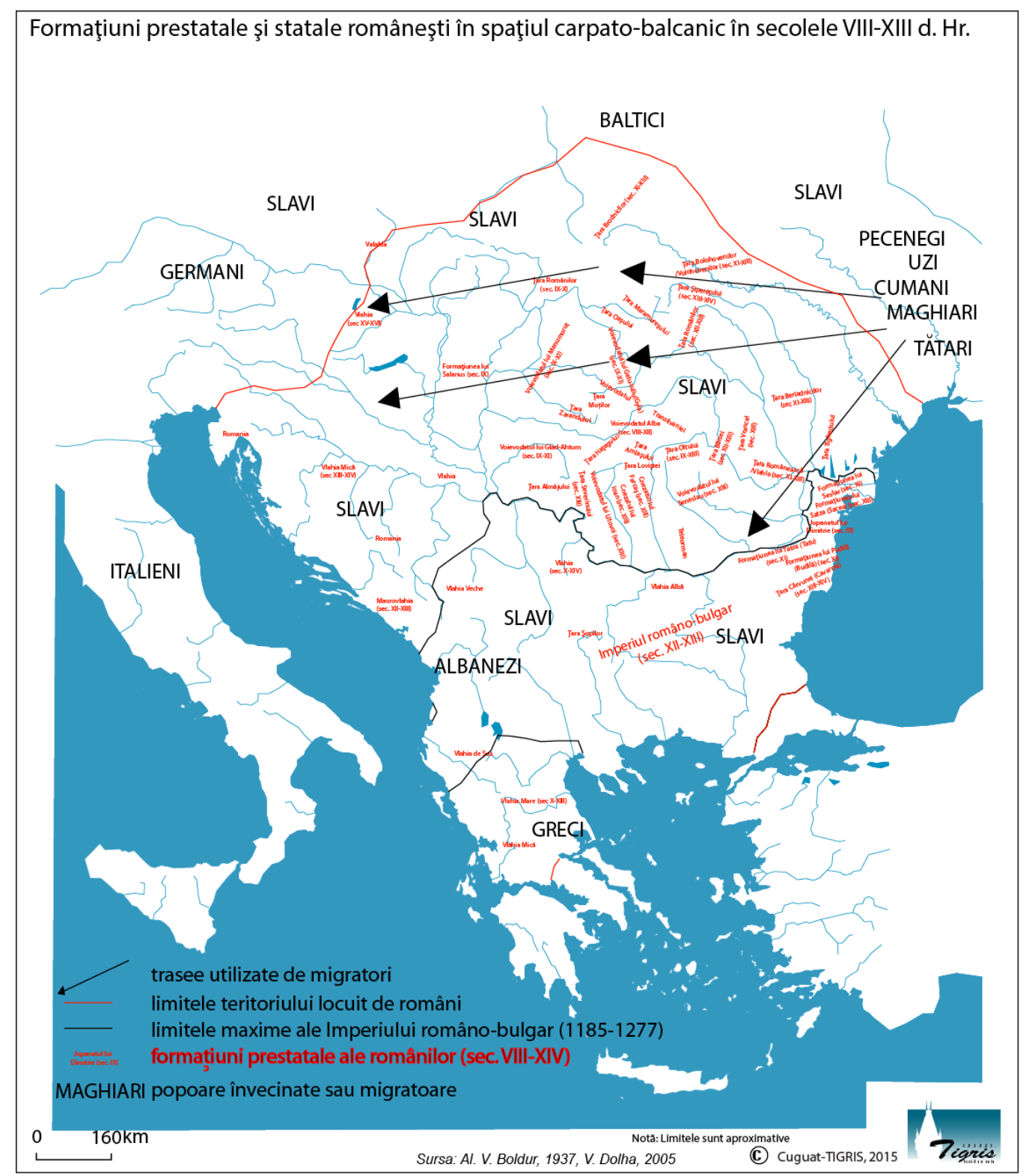

Figure 7 - Prestate political formations and the Romanian states in the the Carpathian-DanubianBalkan space in VIII - XIII A.D

\footnotetext{
${ }^{4}$ Ionel Boamfă, Aspecte geografice reflectate în onomastica Masivului Ceahlău, in Lucrările Științifice ale Seminarului Geografic “Dimitrie Cantemir", no. 24, Iaşi, 2004, p. 329, 331;
} 


\section{Methodology. Problems}

The work methodology comprises two categories of methods - the methods for collecting the anthroponymic information and the methods for the analysis and the interpretation of the onomastic information. The collection methods refer to the sources used for documentation (collections of documents, especially for the $15^{\text {th }}-17^{\text {th }}$ centuries, statistical and fiscal records - cathagraphies, made in the $18^{\text {th }}-19^{\text {th }}$ centuries, yearbooks, phone books especially for the $20^{\text {th }}$ century, sites with public telephony subscribers in Romania, Moldova and Ukraine - for the current period, to which are added the sources that present various dignitaries from the Romanian Principalities in the fourteenth and seventeenth centuries, parliamentarians and ministers from the Romanian Principalities - in the first part of the nineteenth century, from Romania - in the last 150 years and from the Republic of Moldova after 1990, etc.). The anthroponymic data were introduced into a Microsoft Excel file, generally at the current communal administrative level (excluding the Transnistrian territory belonging to Ukraine, where we worked only at the level of the former Romanian counties from 1941-1944), being then aggregated at the level of the interwar Romanian counties (to have a relationship with the same administrative divisions allowing for comparability between different historical periods). After summing up the data for Carp's various variants and derivatives, we calculated per cent values for each century ${ }^{5}$, by reporting the values of each county to the corresponding total, and later the data for the spatial distribution coefficients ${ }^{6}$. The methods used for data analysis and interpretation are the cartographic method and the geographic method. Among the cartographic methods, the realization of the maps was done both by the method of proportional circles (for each century) and by the method of color beams, the method of spatial distribution coefficients (both methods - for each century) and the ascending hierarchical classification method (a synthesis map covering the entire time in which the name was certified), all using the percentage values. The maps were created with the Philcarto program and processed with Adobe Illustrator program.

In accomplishing this, we have struck a number of problems. The first is about the access to data and the fact that the cover with the anthroponymic information is incomplete. The documentary sources, published at least for the extra-Carpathian lands, until the $17^{\text {th }}$ century, are completed in the following centuries (only for historical Moldavia) by the cathagraphies made by the Tsarist occupation administration in 1772-1774 or by the Principality's administration of Moldavia, in 1803 (Condica liuzilor), but the last, already, no longer includes the northwest of Moldavia, occupied in 1775 by the Austrians and renamed

\footnotetext{
${ }^{5}$ An exception is made in the last century, where we separated the first part of the century (until 1940) and a second period, covering the years of the communist regime.

${ }^{6}$ For the calculation of the spatial distribution coefficient we used as the reference variable, the population calculated for each century. We divided the population of each county into the total population. Then, the county percentage of the total number of Romanian bearers of the Carp name was divided by the percentage of the population of each county, resulting the coefficients higher or lower than 1 (a characteristic value at the level of the Romanian space - including the interwar Romania plus Transnistria belonging to Romania in the years 1941-1944). Where the coefficients are bigger than 1, it means that the name is overrepresented in relation to the average (1), and where the values are lower than the unit is sub-representation. We have separated, strictly conventional, a "class" where the value of the spatial distribution coefficient is zero, a sign that the name is not attested at all in that county within that timeframe.
} 
Bucovina. Also, both records do not include the Tighina raya, occupied by the Ottomans as early in 1538. For Bucovina, the information was partially completed by the documents published by T. Bălan and T. Stefanelli, as well as by the highly detailed data provided, in the interwar period (including the interval of Austrian occupation) by the priest D. T,opa, for the villages of the northern part of Bucovina, located between the Prut and the Nistru.

To this paper relates the second problem: the degree of detailing information and the type of anthroponymic data provided by the sources of documentation: if in the documents, the random nature of the anthroponymic mentions is obvious (and we cannot change this reality) from the $18^{\text {th }}$ century, the statistical registrations has mention (if make this), only the man, Anuarul SOCEC al României Mari / the SOCEC Yearbook of Great Romania registered mayors, notaries, teachers, owners of groceries, mills, estates, forests from each commune (in the urban area as well as the owners of restaurants, lawyers, mills, butchers and other activities - often by other nationalities, even in the Old Kingdom), while the phone books in the Communist period (as well as the interwar ones, only for the Capital city and Ilfov County) the drawback of having an extremely small number of subscribers. In addition, sometimes the degree of detail for the same period is different: thus, if the relatively poor information provided at the level of the entire interwar Romania by the SOCEC Yearbook include only a few dozen bearers of the Carp name, Father T,opa's work gives, for the North of the former Cernăuţi County, almost 100 bearers of this patronymic.

Also, for the current period, if the information provided by the national telephony companies in Romania, Moldova, Ukraine and Bulgaria ${ }^{7}$ (with a population coverage with this different service, at both country level and comparatively, between they register only the holders of phone, for the villages and towns of the Olt Country, we have very detailed data from the electoral lists, obtained during the field documentation in June 2004. This is explained in the case of many counties, by the intermittent attestation of the Carp name (recorded, for example, in the eighteenth century, not recorded in the next century, "re-emerged" in the interwar period, not attested during the Communist period, but present again today ${ }^{8}$ ). In some cases, this shortcoming was somewhat "corrected" by the fact that the site with Ukrainian phone subscribers includes (even more often than the subscriber's telephone number, next the address - city, street) and the date of birth of that subscriber. Considering that, at least in rural areas, a subscriber born in the interwar period or during the Soviet communist years, he was very likely to have left his native settlement until today, where the number of current subscribers exceeds 10, we also noted with 1 their presence in the communist and / or interwar periods. In the case of the data recorded in the Microsoft Excel file for northern Bukovina and for southern and northern Basarabia (currently belonging to Ukraine), this presence is confirmed by the interwar sources (by the SOCEC Yearbook of Great Romania and / or by D. T,opa's work). Thus, with the necessary reserves, we also have information for Transnistria, which also covers the $20^{\text {th }}$ century.

\footnotetext{
${ }^{7}$ For the two actual units of Cadrilater (Silistra and Dobrici), overlapped, to the interwar Romanian counties, Durostor and Caliacra.

${ }^{8}$ This is the case of the former Fălciu County: there were registered two bearers of the name in the eighteenth century, 5 - in the interwar period and 46 - nowadays, but both in the $19^{\text {th }}$ century and in the communist period no mention was made. It is unlikely that at these two intervals of "non-identification" of the name, those who disappeared will simply "reappear" afterwards. Similarly, the situation in the former Neamt County is similar, with the first written mention of the name from the $17^{\text {th }}$ century, followed by a "pause" of two centuries (XVIII-XIX).
} 
And, in connection with this issue, we also point to another problem: the same site with Ukraine's telephone subscribers sometimes handles the same subscriber twice (the same name, surname and same address), being probably subscribers with two telephone stations. In these cases, we counted the respective bearers of the name once. Finally, the same site limits searches to a few dozen a day (up to 50): how a name is certified in Ukraine by hundreds and even thousands and tens of thousands ${ }^{9}$, and only 15 subscribers are shown on a page, the search

9 The name Karpo (a deformation of the Romanian form Carpu, frequently attested until the eighteenth century) is attested 232 times, Karpinskaya - is noted 2391 times, Karpinskii - appears 1966 times, Karpiuk - is recorded by 5762 times, Karpov - for 7332 subscribers, Karpova - for 9479, Karpovič is attested 4019 times, and Karpenko appears 47871 times. If in the Romanian space (in southern and northern Bessarabia and northern Bucovina, where the first Slavic forms, rutenised, appear isolated from the eighteenth century - Carpenco and Carpuc - probably a deformation of a Carpiuc - attested each once) such forms may be, to a great extent, the result of a slavicization of Romanian forms, attested in Bessarabia and Bucovina from the previous centuries (thus, in Bessarabia, about one third of the attestations of the $16^{\text {th }}$ century for the whole of Moldova (in the case of the present-day Bucovina, the first attestation dates back to the fifteenth century); in Ukraine (including Transnistria) these are, almost exclusively, the fruit of slavic creation (Ukrainian and Russian) and we doubt that forms such as Karpenko, Karpiuk, Karpova are related to the Romanian ones: Carp(u), Carpe(a), Cărpoi, Cărpoaie, Cărpuş and others. In Transnistria (for which we do not have data from the older centuries), it is possible that the Romanian forms were subjected to a slavization, with the assimilation of the Romanian element in the $18^{\text {th }}-20^{\text {th }}$ centuries, quite a number of times, but the modest presence in (Carp - 155 bearers, of which 80 - in the former county of Râbnița and 14 - in the former Dubăsari county, overlapped mostly over the Transnistrian sector of the Republic of Moldova, compared to 1223 - Karpenko, 350 - Karpov, 457 - Karpova and 116 Karpuk, of which 36 - in the former Dubăsari county) justify us that a large part of the slavic bearers are the result of colonization with allogens (Russians, Ukrainians), practiced in the last two centuries, by the Tsarist and Soviet administrations, a reality present, after 1944, in Bessarabia too and especially in Bucovina. Thus, the former county of Cernăuţi now counts 527 bearers of the variants and derivatives from the analyzed patronym, 122 of which bear the name Carp / Karp, but 132 - they are called Karpiuk, 62 - Karpo, 94 - Karpenko; In the former county of Hotin, which is largely in the administration of the present Ukrainian region of Cernăuți / Chernivtsi, 279 are recorded, out of which 192 bearers of the original variant, Carp, but also Karpenko - 62; the former Romanian Ismail County, which today is part of the Ukrainian region of Odessa, has 88 bearers of the Carp name, out of a total of 228, but 89 are called Karpenko (a variant that already appears in Bugeac since the interwar period), other 19 - Karpova, 18 - Karpov, etc.; In the former county of Lăpuşna (which also includes Chişinău, a city that has grown demographically more than 6 times during the Soviet occupation period) there are 414 bearers of the Carp name, with variants and derivatives, of which Carp are named 236, but it appear the bearers of the Slavic forms: Carpov-46, Carpovici - 25, Carpenco 35, Carpova - 34. In general, the former Romanian counties over Bessarabia and Bukovina occupied by the Soviets do not fall below 100 bearers of name (the exception is the ancient Orhei County, with 91 bearers). For comparison, in Romania, the Moldavian counties, where Carp appears documentary recorded for centuries, have lower values: Covurlui-122, Iaşi -74, Bacău - 54, Fălciu - 46, or Rădăuţi - 81 but here, a part is found in the communes occupied in 1940/1944 by the Soviets), while the Romanian maxim is recorded in ... outside Moldova, in Bucharest, which counts 147 bearers of this name) and in Transnistria (with the reserve that only a part of the Transnistrian-Ukrainian settlements were covered), with the exception of Odessa (which accumulates 1880 out of 2,630 Transnistrian bearers of Carp-related names), only 4 former counties (out of 12 without Odessa) go through 50 bearers of the patronymic: Râbniţa - 209, Golta - 178, Ananiev - 54, Dubăsari - 53. In these counties we recorded more often some Slavic forms: Golta - 38 bearers of the Karpova form, Râbniţa - 91 of Karpenko, Golta - 76, Ananiev - 40, the latter having 10 bearers of Karpovič patronymic. The 
and copying of all Ukrainian subscribers for all (probably) variants and derivatives of Carp would have been extended for a long time, so we chose to extract the anthroponymic information only for the regional and district residences in Herța, northern Bucovina, northern and southern Basarabia and Transnistria, as well as for the towns and some of the communes belonging to the districts / regions overlaid over the territories belonging to Romania in the years 1918-1940 and / or 1941-1944 ${ }^{10}$. Taking into account the large number attested today in Transnistria, even only for the selected localities, we consider that the omission, for objective reasons, of the other localities ${ }^{11}$ does not affect the conclusions of our scientific approach ${ }^{12}$.

Romanian form - Carp - is registered 82 times in Râbniţa County and 14 times - in Dubăsari County, which means that in the first county, more than a third of all variants belong to the Romanian name, which is also valid for more of a quarter of the bearers of all variants recorded in Dubăsari County. In fact, if we omit Odessa, a town developed rapidly after 1792 as a cereals port of the Tsarist Empire, on the site of a Romanian village - Moldovanca -, the 770 Transnistrian bearers of all Carp variants and derivatives amount to a little more than those 545 bearers in Moldavia proper, and not half of the 1751 bearers registered in all Bessarabia (the three regions having comparable populations and areas) and approaching the 777 bearers in the whole of Bucovina (a region that accounts for about one third of the population and the surface of the other 3 regions or even less). In fact, we tend to believe that Odessa (the capital city of the former county and the present homonymous region) attracted mainly immigrants from different regions of the former Empire (whether Tsarist or Soviet) and fewer Transnistrian inhabitants, as and Bucharest, the Capital of Romania, have come to have the largest number of carriers of the Carp name (a reality present since the Communist period), patronymic attested, for centuries, in historical Moldavia. Let us say a few lines and the importance of the Carp name as a stem-variant from which the other forms will have developed (at least in part). It holds $90.5 \%$ in Moldova (493 bearers), $51.2 \%$ in Bessarabia (931 bearers), 33.2\% in Bukovina (258 bearers) and 5.9\% in Transnistria (155 bearers). In this latter region, if we omit Odessa, the 125 bearers of the Carp form would represent $16.2 \%$.

${ }^{10}$ Moreover, for some Slavic variants (Russian and / or Ukrainian - Karpiuk, Karpov, Karpova, Karpovic) we limited the search only to district and / or regional residences and / or to some localities for which we already know that other variants are attested and derived names or one of them appeared in the interwar period.

${ }^{11}$ For example, Odessa, the residence of the homonymous region, sums up 289 of the 350 bearers of the Karpov derivative in all of Bugo-Nistrian Transnistria, 28 of the 37 Transnistrian bearers of the Karpuk name, 872 of the 1223 bearers of the Ukrainian derivative Karpenko, for all variants and derivatives - 1860 of all 2630 Transnistrian bearers of a derivative of the Carp / Karp name are also recorded in Odessa.

${ }^{12}$ A problem or, rather, an impediment (we think of it temporary) is related to the impossibility of a detailed representation at the communal level of the anthroponymic information related to the Carp name. We currently have separate map funds for Romania and the Republic of Moldova at the communal level. We have started to build up the administrative database for the (former) Romanian regions, which are today in the territory of Ukraine (Herța, northern Bucovina, northern and southern Bessarabia) and Bulgaria (Quadrilater), and we will finalize this database for Transnistria wich has a Romanian administration in the years 1941-1944. It will be followed by the re-aggregation of the elementary administrative units (communes, urban settlements) to the limits of the interwar counties (an action which, except for the present territory of Romania and the Republic of Moldova, also involves the drawing of the communal / urban units) and, when this action is completed, we have a detailed map fund for the spatial representation of both the Carp name and for other onomastic, historical, demographic, economic, political, social, cultural, etc. facts. 


\section{The chrono-spatial distribution of bearers of the name Carp}

The first documentary mention of the Carp patronymic dating from 1453 is located in the area of the current village of Filipești, Bacau County, followed in 1479 by another, registered in Suceava, then the Moldavian seat of the voivodship of Moldavia. The following attestations, up to the nineteenth century (in documents, statistical and tax records cathagraphies, lists of deputies elected in legislative assemblies) are almost exclusively Moldovan, with the preponderance of the mentions located in the space between the Carpathians and the Prut.

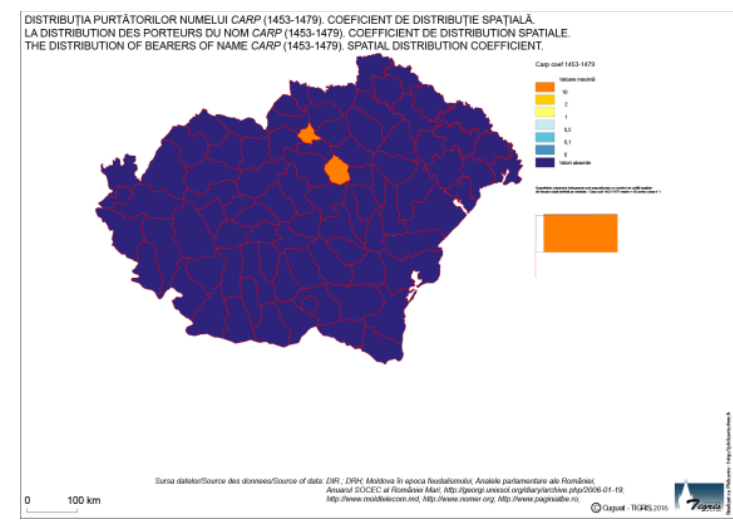

Figure 8 - The distribution of bearers of name CARP (1453-1479). Spatial distribution coefficient

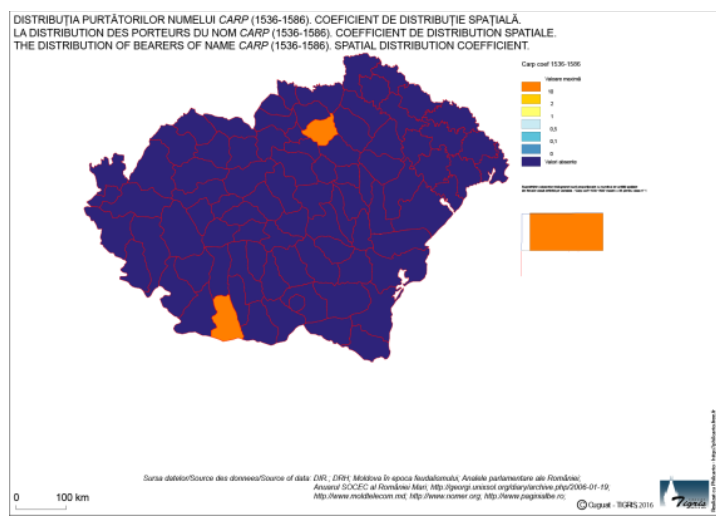

Figure 9 - The distribution of bearers of name CARP (1536 - 1586). Spatial distributin coefficient

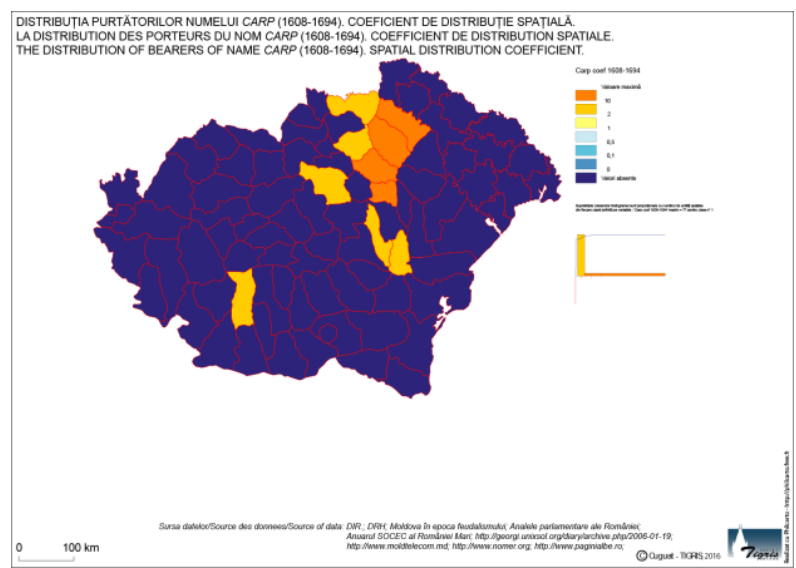

Figure 10 - The distribution of of bearers of name CARP (1608-1694). Spatial distribution coefficient

The only exceptions, somewhat curious, are the attestation, in the $16^{\text {th }}$ century, of a Carp, in the present Oltenia, in the commune of Bobicessti, Olt County, followed in the 
eighteenth century by another mention of a Carpu, at Cârstăneşti-Oteşani ${ }^{13}$, Vâlcea County. For every century, the attestations are modestly numerical: two for the fifteenth and sixteenth and the 18 - in the seventeenth century.

Compared to these values, the $18^{\text {th }}$ century onomastic information represents a true numerical "explosion", the total of attestations being more than four times higher than in the previous century. In the analyzed documentary sources, of which most of the information is provided by the Russian cathagraphy of 1774, there are 79 mentions, 44 - in the form of Carpu and 29 in the Carp version, isolated being the first forms influenced by the Ukrainians - a Carpenco, in Toporăuți (formerly Cernăuţi County) and a Carpuc (probably Carpiuc) at Vetreanca (formerly Hotin County).

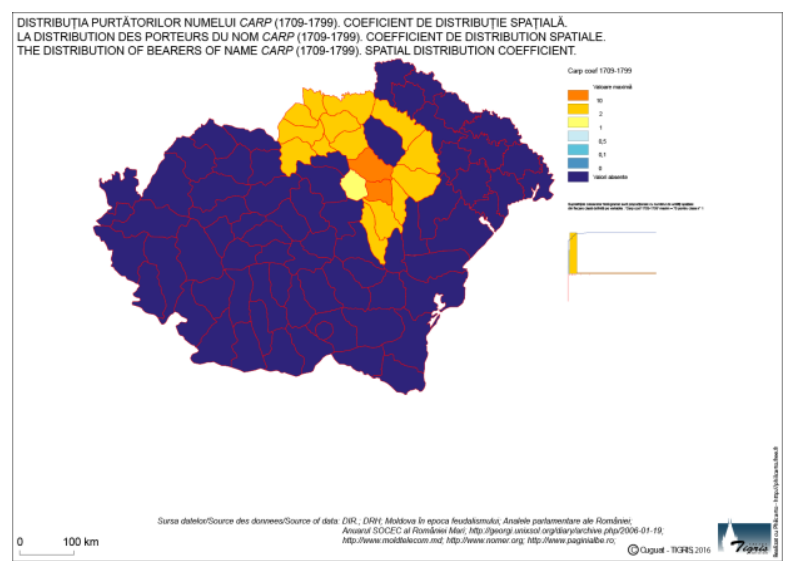

Figure 11 - The ditribution of bearers of name CARP(1709-1799). Spatial ditribution coefficient

Rarely, from the $16^{\text {th }}$ century, both the historical documents and the cathagraphies attest the name Carp and as a baptism name, such a mention appearing in the $16^{\text {th }}$ century: Carp, spătar (boyar), brother with Aniţa, wife of Solomon Bârlădeanu, vornic (an functionar) in Botoșani, in $1648^{14}$, another Carp, the son of Rusu Ionasco, in the Orhei County ${ }^{15}$, and in a document from Izvod de banii scutelnicilor din 1827, is mentioned pitar Carp Găluşcă ${ }^{16}$. This fact is ascertained, both in the interwar period (in the SOCEC Yearbook of Great Romania, $1925)^{17}$, and today in Basarabia, as is shown by the database of Moldtelecom's telephone

\footnotetext{
${ }^{13}$ If it is not a inhabitant of the village of Cărstăneşti, Topolog district, Argeş County, already disappeared at the end of the $19^{\text {th }}$ century, according to Marele Dicționar Geografic al României / the Great Geographical Dictionary of Romania, vol. II, p. 297

${ }^{14}$ N. Stoicescu, Dicționar al marilor dregători din Țara Românească și Moldova în secolele XIV-XVII, Editura Enciclopedică Română, București, 1971, p. 349.

${ }^{15}$ Idem, p. 440.

${ }^{16}$ Th. Codrescu (ed.), Uricariul, vol. VII, Tipografia Buciumului Român, Iași, 1886, p. 169.

${ }^{17}$ For example, a shoemaker from Furmanca, Ismail County was called Carp Cernega, being mentioned in Anuarul SOCEC al României Mari / the SOCEC Yearbook of Great Romania, vol. II, p. 2083 (171); among the shoemakers from Cineşeuţi / Cenuşăuţi, Orhei County, there is a Carp Cușmir, op. cit., p. 2097 (185); a Carp Popovici was a parish priest in Vadul Raşcov, Soroca County, op. cit., p. 2141 (229), etc.
} 
subscribers ${ }^{18}$, although such situations are isolated, west of the Prut (a Carp Mezdrea, Candrenii Dornei, Câmpulung County ${ }^{19}$, in 1925, a Carp Constantinescu, Ploiesti, the Yearbook with phone subscribers from 1959 or the subscribers named Carp Dragomir, Priboieni, Argeș County, Carp Zorilă, Brăila, Carp Christescu in Bucharest, Carp Paliescu, in Cluj, Carp Vijniceanu, Târgoviște, Carp Dinu, Mârșani, Dolj County, Carp Iftode, Vârlezi, Galați County, Carp Nedelcu, Galați, Carp Filca, Slobozia, Carp Oprea, Popeşti-Leordeni, Ilfov county, Carp Nazdraciov, Ploieşti, Carp Mitu, Comăneşti, Suceava county, Carp Simionov, Suceava, Carp Hariton, Tulcea, Carp Oprea, Băile Olănești, of former Romtelecom company in $2008^{20}$ ). This preservation of the name as the surname too reinforces the idea of its perpetuation on the "direction" tribe name - baptismal name - surname.

Keeping the old tribal name of the Carpi as patronymic, both to the nobility and to the peasants, might be an argument in favor of the fact that both the old Carpo-Dacian nobility (tarabostes) and the simple people (comati) have preserved this anthroponym, as a baptismal name, and he could become - both boyars and people - surnames (family names). In the first documentary mention of the name, dated April 5, 1453, Carp is attested, as mare vătaf (great functionary $)^{21}$. Instead, in a document dated April 5, 1627, another Carp, with little rank, somewhat to a mayor of Maliniță (Malinți) ${ }^{22}$, a village in the Hotin County, appeared. In a document dated June 16,1768, among the leaders of the village of Dorna, in the district of Câmpulung, in the county of Suceava, is mentioned Ion Carpe ${ }^{23}$. In the Russian cathagraphy of 1772-1773, it is mentioned that the village of Potângeni, Copou district, in the county of Ieși belongs to the logofăt (great boyar) of Gheorghii Carp ${ }^{24}$. A year later, in the next Russian

${ }^{18}$ We have selected some examples: in Berezlogi, Orhei district, Carp Andronachi is mentioned, in Chișinău - Carp Creciun, in Orhei - Carp Erhan, in Bălți - Carp Ursachi, in Basarabeasca - Carp Rusu and others.

${ }^{19}$ Anuarul SOCEC al României Mari, vol. II, Editura „SOCEC \& Co.” Soc. Anon., București, 1925, p. $901(51)$

${ }^{20}$ Somewhat surprisingly, of the 24 Carp subscribers, only 4 are located in Moldova and southern Bucovina, remaining after 1944 in Romania (two in Galați County, respectively in Suceava County). However, as for the total number of subscribers for whom the surname is Carp, the fact that in Bucharest (with 147 name carriers) and in the counties of Brașov (with 25 mentions), Constanţa (34), Tulcea (29) are registered at least as many or even more bearers of the name than in the former inter-war Moldovan counties (with 24 attestations), Dorohoi (25), Neamt (23), Tutova (22) - all with old historical mentions of the name, would not mean that the traditional distribution of the name covers Muntenia, Dobrogea or Transylvania, and in this case we consider that the custom of giving this patronymic and surname has been preserved to a large extent by Moldovan natives, migrating to other regions of the country in the post-war period. We base our argumentation on the fact that the historical testimonies of the name Carp are only found in historical Moldavia and the fact that in Bessarabia part of it, this habit, also with older historical attestations, is even more common today (37 attestations, only in the Bessarabian territory of the Republic of Moldova) than in the Romanian territory west of Prut. It is also noted that all Carp's mentions as a surname, up to and including the interwar period, are located in historical Moldova.

${ }^{21}$ Documenta Romaniae Historica. A.Moldova, vol. II (1449-1486), Editura Academiei, București, 1976, p. 415

${ }^{22}$ Documenta Romaniae Historica. A. Moldova, vol. XIX (1626-1628), Editura Academiei, București, 1969, p. 226.

${ }^{23}$ T. V. Stefanelli, Documente din vechiul ocol al Câmpulungului Moldovenesc, Librăriile SOCEC \& Comp. și C. SFETEA, București, 1915, p. 97.

${ }^{24}$ Moldova în epoca feudalismului, vol. VII, partea I, Editura Știința, Chișinău, 1975, p. 200. 
cathagraphy, in the village of Bursuceni-Vereşti, district of Siret, Botoşani County is mentioned a Gheorghe Carpu, polcovnic (officer) ${ }^{25}$. In the village of Toporăuţi, in the same county, the same Russian cathagraphy in 1774 attests to the presence of three Carp and Carpenco bearers ${ }^{26}$, and among the inhabitants of the village of Carapciu pe Ceremus, in the county of Cernăuţi, a Carp is mentioned in $1782^{27}$, and in 1768 In 1803, in the village of Năiteştii razăşseşti, district of Pereschiv, Tutova County, there is a Andrieş Carp ${ }^{28}$, Ilie Carp ${ }^{29}$ appears in the county of Orhei, and in Câmpulung Moldovenesc, already under Austrian occupation, a Mihăilă Carpe, on September 29, $1825^{30}$. In the nineteenth century, the volumes of the Parliamentary Annals of Romania mention, as deputies in the Common Assembly of Moldova, Grigori Carp, spătar, in 1836, Gheorghe Carp, major in 1841, or Kostachi Carp, postelnic, in 1846, all the deputies of Iaşi. In the ad-hoc Assembly of Moldova, in 1857, a Nicolae Carp, spătar, deputy from Vaslui, appeared, and in 1870 start his parliamentary career the much-known boyar Petre P. Carp, also as deputy of Vaslui, in the next half-century, several times, deputy, minister and even prime minister. Finally, without the exhaustion of the examples, the work of Father D. T,opa mentions the presence of many villagers called Carp in the villages in the northern extremity of Bucovina, between Prut and Nistru - Babin, Gavrileşti, Ivancăuţi, Revacăuţi, Toporăuţi, many of whom had the name already with the name ruthenized since the nineteenth century, in forms such as Carpeac, Carpiuc, Carpo ${ }^{31}$.

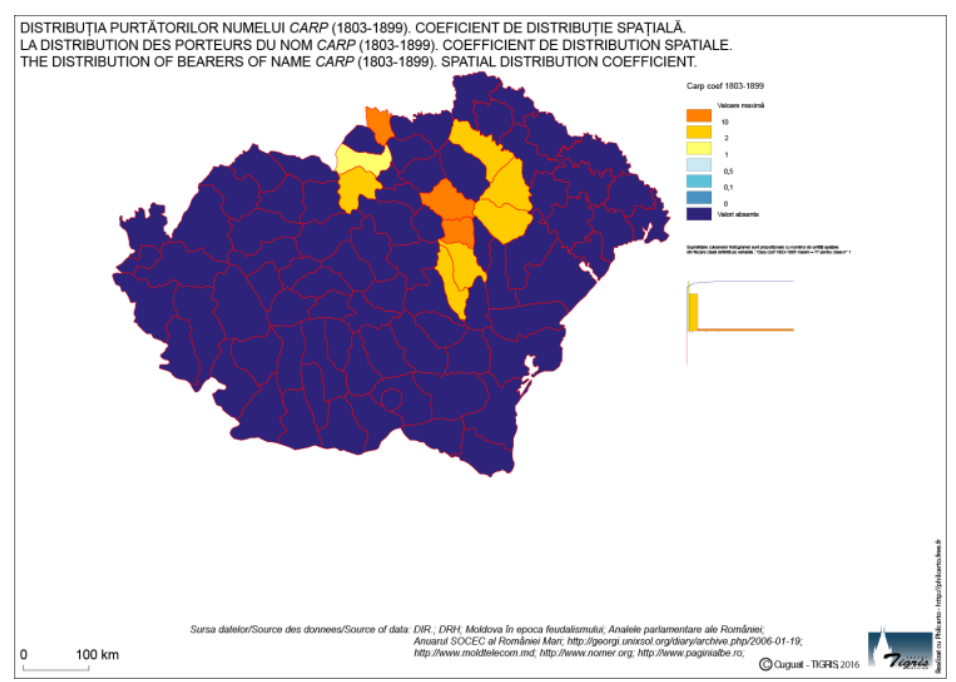

Figure 12 - The distribution of bearers of name CARP (1803 - 1899). Spatial distribution coefficient

On the other hand, the presence of the bearers of this name among the dignitaries had remained a tradition in the last century: besides the already mentioned Sandu Carp, deputy of

\footnotetext{
${ }^{25}$ Moldova în epoca feudalismului, vol. VII, partea a II-a, Editura Știinţa, Chişinău, 1975, p. 193.

${ }^{26}$ Moldova în epoca feudalismului, vol. VII, partea I, p. 399

27 T. Bălan, Documente bucovinene, vol. VI, Editura Casa Școalelor, București, 1943, p. 244

28 Th. Codrescu (ed.), Uricariul, vol. VII, p. 344.

${ }^{29}$ Th. Codrescu (ed.), Uricariul, vol. VIII, Tipo-Litografia Buciumului Român, Iași, 1886, p. 269.

${ }^{30}$ T. V. Stefanelli, Documente din vechiul ocol al Câmpulungului Moldovenesc, p. 391.

${ }^{31}$ D. Țopa, Românismul în regiunea dintre Prut și Nistru din fosta Bucovină, Editura Casei Școalelor, București, 1928, p. 61-172.
} 
Durostor, in 1932, we mention Grigore P. Carp, a deputy from Bacău, elected in 1926, Nicolae Carp, deputy of Prut (Vaslui), elected in 1939, Zenovia Carp, deputy elected in 1961, in Aroneanu riding, Iaşi region, or Mihai Carp, deputy of Bihor, elected in 1990. The habit passed to the east of Prut, where in November 2014 were elected deputies in the Chişinău Parliament, Lilian Carp (Străşseni) and Eugen Carpov (Chișinău), the latter being also a minister in the Moldovan government. Among the ministers present in the governments of Romania, besides Petre P. Carp (who was also the head of the Romanian government twice), we mention Anton Carp, a Buzău-born citizen, a member of the Bucharest Executive in the years 1907-1908.

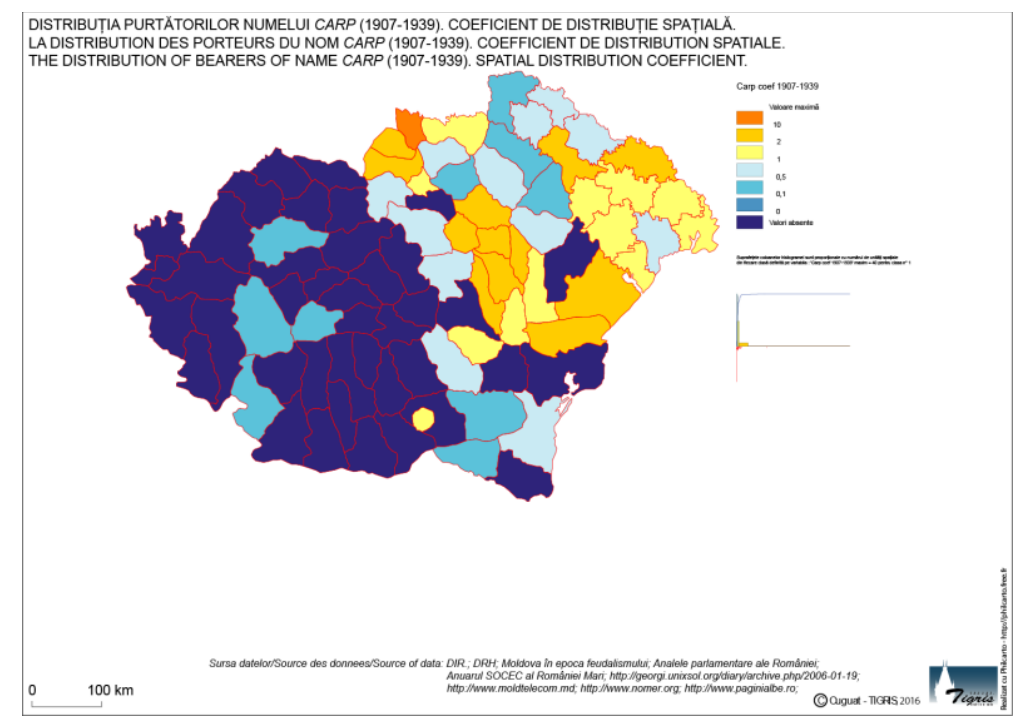

Figure 13 - The distribution of bearers of name CARP (1907 - 1939). Spatial distribution coefficient

The patronymic also entered in the toponymy. We do not have older information, but we can give some examples, collected either from written sources (dictionaries, encyclopedias), or cartographic and / or administrative, for the past over a hundred years. More than a century ago, a estate from Cătina commune, Buzău County was called Carp ${ }^{32}$, and in the same county there were also an Izvorul Carpelui / Carpelui Spring and a Măgura Carpelui / Carpelui Hill (Peak); in Rogojeni ${ }^{33}$, Covurlui County, was a Valea Carpinei / Carpina Valley $^{34}$. Part of the Coiteasca hamlet, the village of Săgeata, Buzău County, was called Cărpuleasa, the same - an estate, within the same hamlet, and a forest from the Carpul estate was named Cărpuleasa ${ }^{35}$. A village in the commune of Moara, Suceava County, still bears the name Moara Carp, another one in the commune of Țibăneşti, Iaşi County was named Tungujei-Carp, the older name of Mihail Kogălniceanu village, Țigănaşi commune (the same county) was Rateş Carp, a Basarabian locality in the former county of Cahul is called Cărpeşti (though the Cârpeşti variant is more common, another village bearing this name being

\footnotetext{
${ }^{32}$ Marele Dicționar Geografic al României, vol. II, Stab. Grafic J. V. Socecŭ, București, 1899, p. 200.

${ }^{33}$ Today, a village in the Suceveni commune, Galați County.

${ }^{34}$ Marele Dicționar Geografic al României, vol. II, p. 217-218.

${ }^{35}$ Idem, p. 297.
} 
mentioned, since 1436, in the county of Fălciu ${ }^{36}$, both of which are mentioned by D. Frunzescu in 1872, in the form of Cârpesci, a name that he wore and an isolated home from Gorj County ${ }^{37}$ ), and a hill south of the Coarnele Caprei commune, Iaşi County is called Dealul Cărpoaiei / Cărpoaiei Hill. A brief analysis of the distribution of toponyms related to the Carp patronymic reveals their presence especially in Moldavia, on both sides of the Prut (but more notable to the west of this river), with an immediate extension to the south, in a Wallachian county, Buzău, neighboring Moldavia. Of these toponyms, the localities called Cârpeşti / Cârpesci are mentioned with caution, the name being derived from the substantive cârpa $\breve{a}^{38} /$ cloth, as in the case of other villages called Cârpiţi or Cârpiceni.

Starting to the interwar period, the name begins to penetrate west to the Carpathians, area united with Romania in 1918, after the patronymic had begun to be certified in the south of the country (e.g. in Buzăa $u^{39}$ ) since the first years of the last century, but most of them concentrating on the Capital city ${ }^{40}$. Also in the interwar period the name is certified, isolated, even in Quadrilater, in the former Durostor County ${ }^{41}$. In the form of Carpina, the patronymic is also recorded in the Aromanians (T. Papahagi, 1922). Also, with the above-mentioned reservations, we mention that few names, too, will also be present in Transnistria. The most numerous are the ones in Bucovina (many of which were recorded by D. Topa), but a large number of carriers of Carp's variants and derivatives were recorded in Moldavia between the Carpathians and the Prut and in Basarabia. The total number of bearers of the name (with all variants and derivatives) exceeds 280.

${ }^{36}$ C. Burac, Ținuturile Țării Moldovei până la mijlocul secolului al XVIII-lea, Editura ACADEMICA, București, p. 476.

37 D. Frunzescu, Dicționar topografic și statistic al României, Tipografia Statului, București, 1872 , p. 99.

${ }^{38}$ However, in this case, there is, indirectly, a link with the name of the tribe of Carpi. There is a hypothesis that both this tribal name and the Carpathian Mountains would come from a Thraco-Dacian term, with the meaning of rock (in the form of karpë, the term, precisely with this meaning, exists in Albanian, a descendant direct of a Balkan native idiom, llirian or Thracollirian, or rather a Thraco-Dacian), in which case the etymology of the name of Carpathians refers to the rocky mountains with many rocks, and the Carpi - to the fact that they are they were steadfast like the rock. From the Thraco-Dacian term a Romanian word cârpă might have evolved, which created some toponyms - Cârpa, the former name of a Banat village, located in the Timiş-Cerna Corridor, renamed Valea Timișului (in order to eliminate the pejorative character of the old name) - respectively Dealul Cârpoc / Cârpoc Hill, a name on the border of the village of Boiţa, in the western extremity of the Olt Country. The linguists have objections to the phonetic evolution of a Thraco-Dacian *carpă in cârpă, but there is at least one exception to the Latin rule of an changed in Romanian în/ân: the Latin word tardivus gave târziu / late in Romanian. In both cases, the possible etymological connection with the rocky, substrate is given by the location of the two geographic elements near or in the high mountain range: the village of Cârpa is situated in a corridor separating the Southern Carpathians (RetezatGodeanul) from the Western Carpathians (Banat Mountains), while the height at the border of the village of Boitza lies immediately north of the Cindrel Mountains.

39 In 1908, between the members of the Government, has Anton Carp, born in Buzău.

40 In the phone yearbook for the year 1937, Abonații S.A.R. de telefonie. București și jud. Ilfov, in Bucharest has registered 11 bearers of the family name Carp.

41 Sandu Carp was deputy of Durostor, in 1932. 


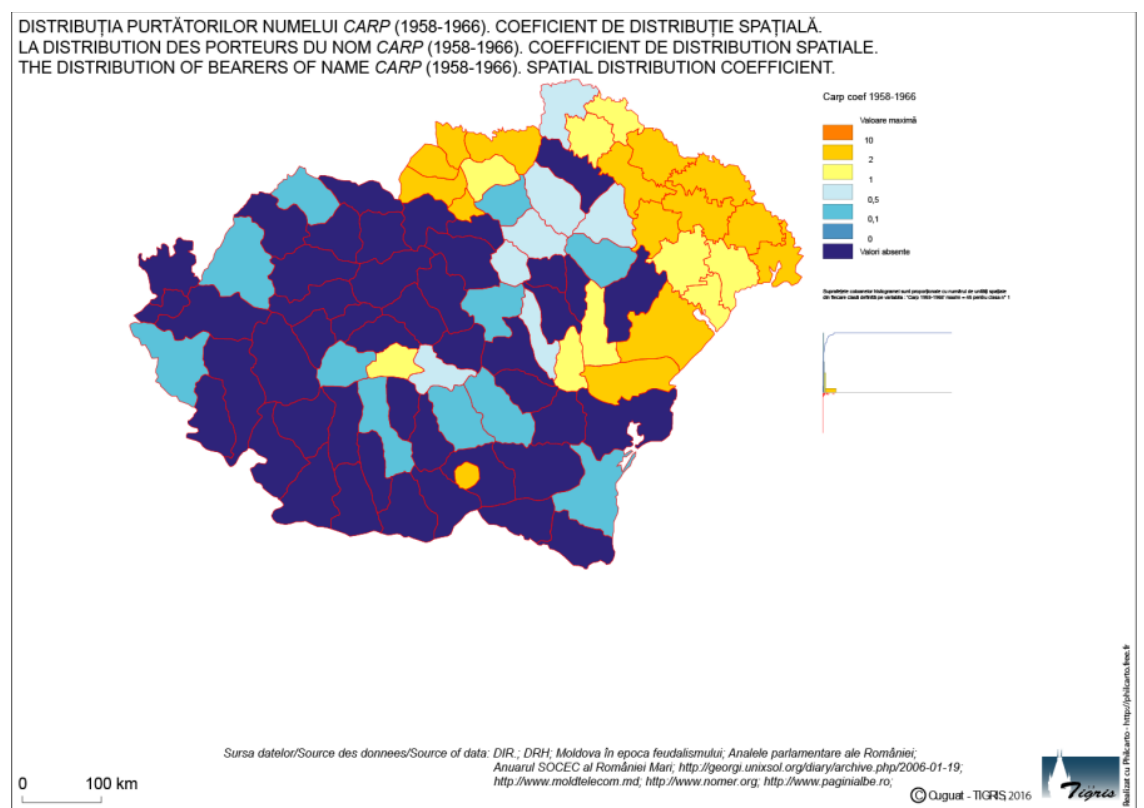

Figure 14 - The distribution of bearers of name CARP (1958-1966).Spatial distribution coefficient

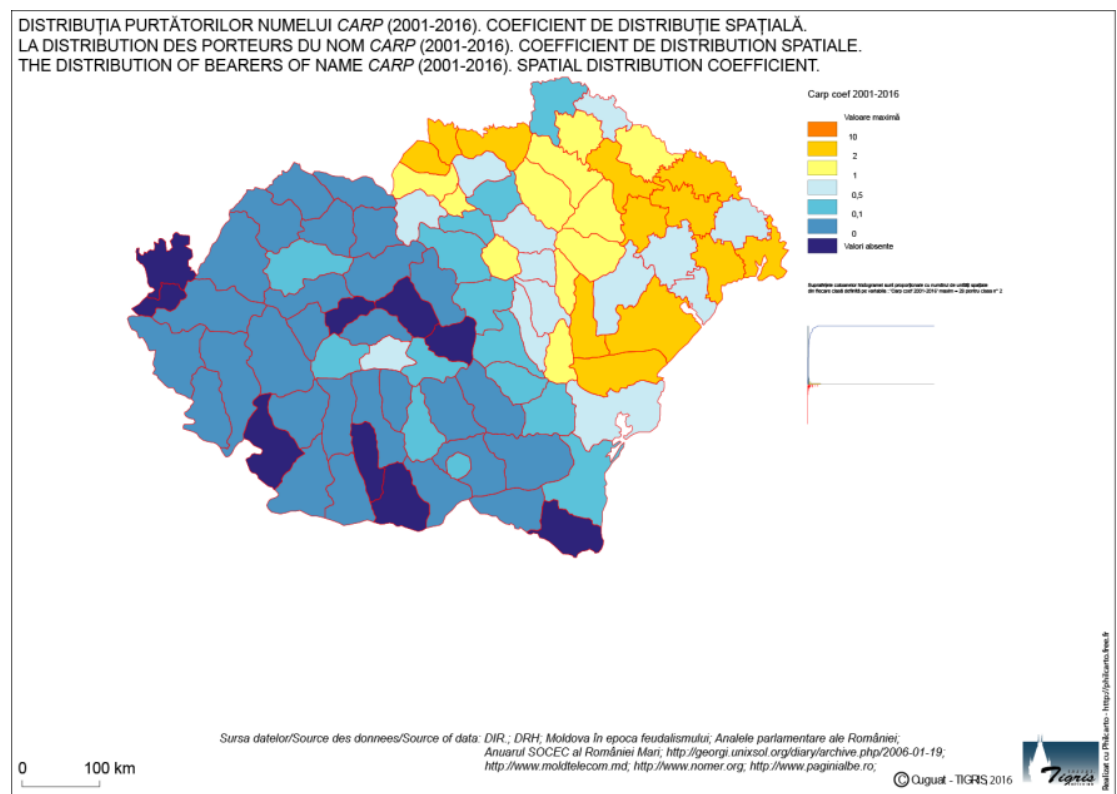

Figure 15 - The distribution of bearers of name CARP (1958 - 1966). Spatial distribution coefficient

For the post-war period (over which the Communist regime overlapped), we have more gaps in information, even more modest than for the interwar period. If, for the current territory of Romania, the information was provided predominantly by the 1958 telephone directory (for Bucharest) and by 1959 (for the rest of the country), in the Soviet occupied 
territories during the Second World War, we recorded to a great extent that living in the Basarabian, Bucovinian and Transnistrian settlements, with the same mentioned caution, those born before or during the communist period and still living in these localities. Thus, most of the entries - more than 40 for each region - were registered in the remaining regions (Basarabia - especially in the former counties incorporated in the former Ukrainian SSR northern part of Bucovina and Transnistria), and for the current territory of Romania, Bucharest have collected 27 mentions, more than double than for the counties of Moldavia (12). The number of bearers of the name in the south and west of the country is even smaller: 4 in Muntenia and Transylvania and only one in Dobrogea, Banat, Crişana and Maramureş. The total number of the bearers of names (with variants and derivatives) is 219 .

The most comprehensive statistics (both regarding the number of name bearers and registered variants) were attested in the current period, at the beginning of the third millennium. If the total number of bearers of all variants and derivatives exceeds 6100, amounts of several hundred bearers are recorded again in the eastern regions. On the first position, with 2630 mentions, is Transnistria this time, although here Odessa concentrates 70\% of the total. Then follow Basarabia, with 1751 mentions, Bucovina - with 777 and Moldova with 545. In the other regions of the country, we have recorded only 404 name bearers, out of which one third (147) are in the Capital city. Of the southern and western regions, there are again more than 50 mentions, Transylvania (82), Dobrogea (64) and Muntenia (58), the other number of bearers being less than 20 in each (and, on the whole, Oltenia, Banat, Crisana, Maramures and eastern Transylvania collect only 43 mentions). For the last decades, starting from the early years of the last century, two tendencies are emerging: the migration from the eastern part of the country (especially from Moldavia between the Carpathians and the Prut) of some bearers of the name Carp to Muntenia (firstly to the Capital city) and Transylvania, but (especially after 1950) to Dobrogea too, respectively, the rapid increase (also by immigration, but from the rest of the USSR - probably, especially from the Ukrainian SSR and Russian RSFS) of those settled in northern part of Bucovina, Basarabia and Transnistria of some bearers of Slavic forms of the name (if they are related to the Romanian patronym Carp): Karpenko, Karpiuk, Karpov and others ${ }^{42}$.

\footnotetext{
${ }^{42}$ Although it is difficult to estimate the impact of this process, probably a part of the bearers of these names, in Slavic linguistic "coat", are the result of assimilation (ethnic and then patronymic) of some ethnic Romanians, especially in northern part of Bucovina and of Bessarabia isolated fact, attested even from the $18^{\text {th }}$ century), in southern Bessarabia and probably, to a lesser extent, even in Transnistria.
} 


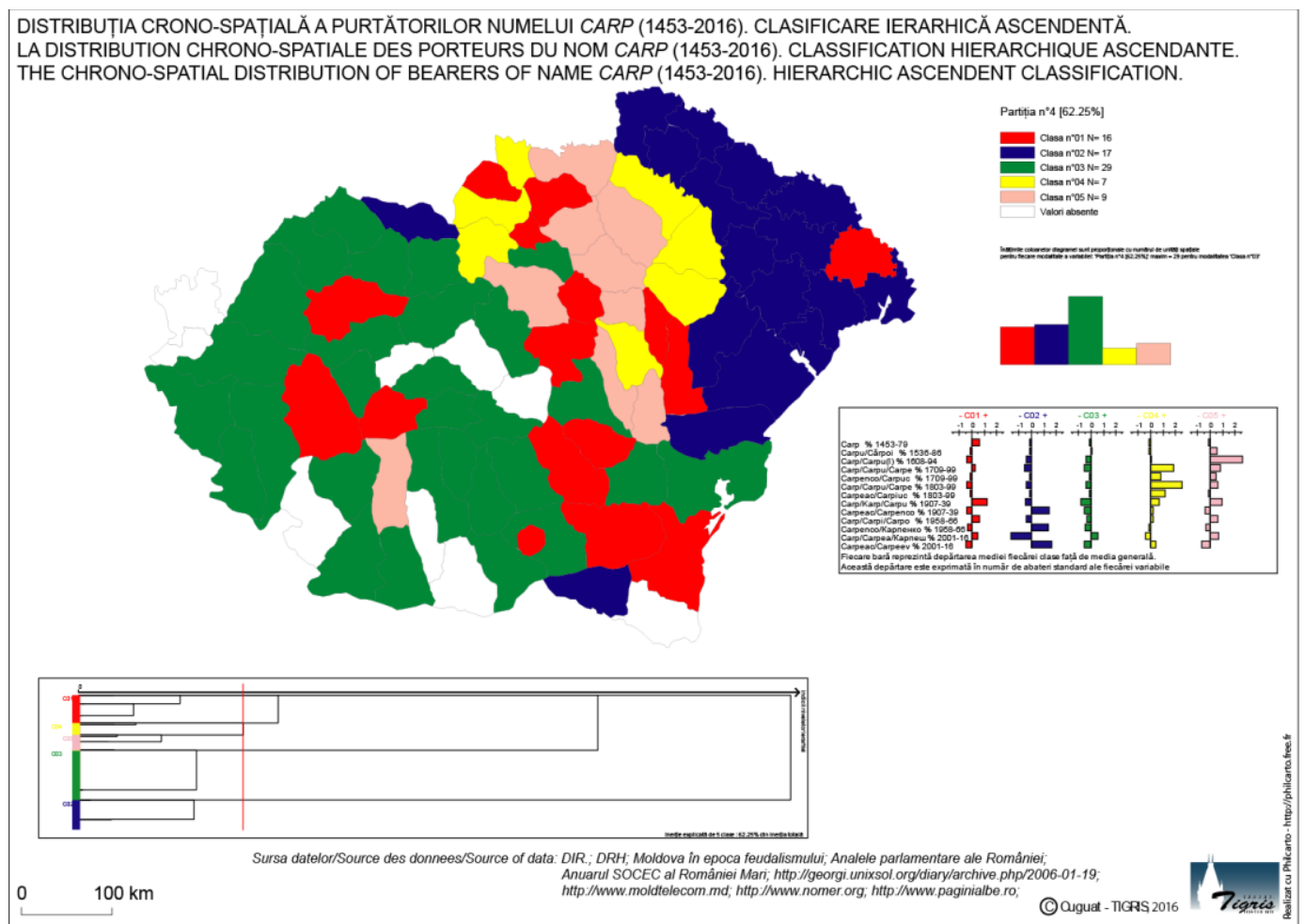

Figure 16- The chrono - spatial distribution of 14 - The distribution of bearers of name CARP (1453 - 2016). Hierarchical ascendant classification

brief mention related to some of these forms. Thus, the toponyms in the form of Izvorul Carpelui and Măgura Carpelui seem to have evolved from a derivative, perhaps with a diminutive role, Carpel $(u)^{43}$, noted in the interwar period in the SOCEC Yearbook of Great Romania, in several places in Bucovina, in the form Karpel, in the counties of Câmpulung, Storojineț and Cernăuţi. On the other hand, the Cărpuleasa (feminine) form, in which a Buzău estate and a forest are noted, seems to derive from a Carpul or, perhaps, from a Cărpulea, a form that appears in a Cyrillic alphabet - Карпуля = Carpulia - at Tighina, nowadays. Finally, the Carpina form for a valley in the former Covurlui County is the same as that recorded in the interwar period at the Aromanian. Again, we note that all forms - in anthroponymic and / or toponymic variants - appear in historical Moldavia: Carpel(u) / Karpel, Carpul / Cărpulea / Карпуля and Carpina respectively. The only untested form in Moldavia - but only in Oltenia, in the Middle Ages $\left(16^{\text {th }}\right.$ century $)$ - is the surprising mention of a patronimic Cărpoi ${ }^{44}$, but in

\footnotetext{
${ }^{43}$ If it is not a form of Carpe, it is also attested in the $18^{\text {th }}-19^{\text {th }}$ centuries, also in Bucovina, more precisely in the old district of Câmpulung Moldovenesc.

${ }^{44}$ The early presence of this patronymic in the eastern Oltenia and of Carpu form in the next century, also there (or in the west of Muntenia, if the village mentioned at that time is that Cărstănești, disappeared in the meantime) seem to surprise, but there is a possibility of emigration, isolated, also from Moldova, through the north of Muntenia. We do not know how old are the toponyms related to the Carp patronymic, noted more than a century ago, in Buzău County, but they seem to indicate, with reasonable reserves, the beginning of a road that would have begun from southern Moldova (from one of the former Tecuci or Covurlui counties), from the confluence of the Buzău River with the Siret, then
} 
the XVII-XVIII centuries there are recorded in several places in Moldavia the feminine variants (such as Cărpoae / Cărpoaei / Cărpoaii) - in the former inter-war counties of Bălti, Iaşi, Vaslui, Lăpuşna - or by toponyms such as Dealul Cărpoaiei (as we have already mentioned in Iaşi County).

We complete this information with explanations about the meaning of the patronymic. N. A. Constantinescu, in Dicționar onomastic românesc / Romanian Onomastic Dictionary (1963), quoted by https://dexonline.ro, states that the name derives from the greek Kó $\rho \pi \mathbf{o} \varsigma<$ $\boldsymbol{\varkappa \alpha \rho \pi \hat { ~ } \varsigma}=$ fruct / fruit. After the website www.namespedia.com, the patronymic would be a "Slavic bible name"45. Probably a considerably part of the Slavic bearers - Karpenko, Karpiuk, Karpov, Karpovič (especially in Ukraine and Russia) - derives from this Greek form, also taking into account the Ukrainian and Russian peoples' belonging to the Orthodox world, or has this Slavic origin. Regarding the name in the Romanian form - Carp - and its derivatives on local linguistic field (Carpea, Carpel, Carpeş, Carpiş, Carpina, Cărpoi, Cărpoaie, Carpulea / Cărpulea and others), we consider that this etymology can no longer be supported, at least not exclusively.

\section{Conclusions}

We can make, in short, some findings:

- The Carpi, as a Thraco-Dacian tribe, appear several times in the eastern part of the former Kingdom of Dacia (in the $1^{\text {st }}-4^{\text {th }}$ centuries), the area where they lived was between Siret and Prut probably disappeared in the future Basarabia), their disappearance not being exclusively related, first of all, to the human losses resulting from the frequent conflicts with the Romans (until 318 AD) or the forced emigration carried out by the Roman emperors (after AD 270), but to their passage from the $4^{\text {th }}$ century to Christianity into Roman linguistic "coat" (an idea argued by linguistic, ethno-folkloric, archaeological, political-administrative elements and, in the case of face, through the probable perpetuation, in the anthroponymic form - Carp -, of the old tribal name, by the onomastic ones);

- In the same area inhabited by the Carpi, since the fifteenth century, the various written references (documents, statistical records, directories, telephone books, etc.) constantly attested in historical Moldavia (the territory between the Carpathians and Nistru), the bearers of the Carp name, preserved, after the renunciation of the tribal attribute, as a baptismal name and penetrated, especially from the $17^{\text {th }}-18^{\text {th }}$ centuries, and as double name (surname), although, especially in Basarabia not exclusively), the patronymic continues to be used later (until today) as a baptismal name too;

- In the northern and eastern regions of historical Moldavia (Bucovina, Basarabia), the first Slavic forms appeared, rarely, in the $18^{\text {th }}$ century, as a result of the assimilationist politics, tolerated or even encouraged by the imperial occupying states (The Austrian Empire, the Tsarist Empire, continued by the Soviet Union), and the settlement of some alogens (to a great extent of Slavs: Russians and / or Ukrainians) in these regions (as in Transnistria);

along this water course from the downstream (commune of Săgeata) to the upstream (Cătina commune), and through the Wallachian Subcarpathians, it could have reached western Muntenia and / or in the eastern part of Oltenia. Perhaps, also, the onomastic mentions of the name in the west of the Olt Country, marked at Bradul (settlement of the town of Avrig), from the interwar period, would also come from.

${ }^{45} \mathrm{http}$ ://www.namespedia.com/details/Carp, September 7, 2016. The etymology seems at least strange, as the same site asserts that the language in which the patronymic was formed is ... Romanian! 
- From the end of the $19^{\text {th }}$ century, both toponymic and anthroponymic certified, there are migratory flows towards Wallachia (it is possible that such a medieval, isolated, nonconsistent numerical flow to explain the medieval patronymic mentions of the name in the eastern Oltenia and / or western Muntenia), including (first of all) to Bucharest (became, since 1862, the unique Capital of the new Romanian state), but also to Dobrogea and, after 1918, the flow of another stream to Transylvania, less to the other regions from southern and western Romania today, and even rarely, to the Balkan regions inhabited by Aromanians;

- With the tendency to emigrate of some of the names' bearers to the southern and western regions of the country - a tendency found particularly in the last century - most of the bearers of the name are still attested in the old historical Moldavia.

Taking into account the geographic distribution of the name, constantly attested in the Moldavia between the Carpathians and the Nistru, over the past 5 centuries (and even to the east of the Nistru in the last century), based on the above arguments, we consider that the Carp patronymic can continue the presence, from the final part of antiquity, of the old tribe of the Carpi, whose descendants are the Moldovan Romanians today.

\section{References:}

1. Arbore Z. (1904), Dicționarul geografic al Basarabiei, Atelierele Grafice SOCEC\&Co., București;

2. Bălan T. (1933-1941), Documente bucovinene, vol. I-VI (1507-1883), vol. I (1507-1653), vol. II (1519-1662), vol. III (1573-1720), vol. IV (1720-1745), vol. V (1745-1760), vol. VI (17601883), Cernăuți (vol. I-V), București (vol. VI);

3. Boamfă Ionel (2004), Aspecte geografice reflectate în onomastica Masivului Ceahlău - Lucrările Stiintifice ale Seminarului Geografic "Dimitrie Cantemir", nr. 24, p. 327-333, Iaşi;

4. Bogdan D. P. (1938), Acte moldovenești dinainte de Ștefan cel Mare, Fundația Regele Carol I, București;

5. Bogdan D. P. (1947), Acte moldovenești din anii 1426-1502, București;

6. Bogdan I. (1902), Documente și regeste privitoare la relațiile Țării Rumânești cu Brașovul și Ungaria in secolul $X V$ și XVI, Atelierul Grafic I V SOCECU, București;

7. Burac C. (2002), Ținuturile Moldovei până la mijlocul secolului al XVIII-lea, Editura Academica, București;

8. Codrescu Th. (1871-1895), Uricariul, vol. I-XXV, Editura Buciumul Românu, Iași;

9. Constantinescu N. A. (1963), Dicționar onomastic românesc, Editura Academiei, București;

10. Donat I., Pătroiu I., Ciobotea D. (2000), Catagrafia obștească a Țării Românești din 1831, Editura Helios, Craiova;

11. Frunzescu D. (1872), Dicționar topografic și statistic al României, Tipografia Statului, București;

12. Grigorovitza Em. (1908), Dicționarul geografic al Bucovinei, Atelierele Grafice SOCEC\&Co., București;

13. Iorga N. (1901-1913), Studii și documente cu privire la istoria românilor, vol. I-XXVI, Editura Ministerului de Instrucție, București;

14. Lahovari G. I., Brătianu C. I., Tocilescu Gr. G. (1898-1902), Marele Dicționar Geografic al României, Stab. Grafic J. V. SOCECŬ, București;

15. Neagoe Stelian (1995), Istoria guvernelor României de la începuturi - 1859 până în zilele noastre - 1995, Editura Machiavelli, București;

16. Papahagi T. (1922), Antologia aromână, București;

17. Petrescu-Dîmboviţa M., Daicoviciu Hadrian, Bârzu Ligia, Teodor Dan Gh., Preda Florentina (1995), Istoria României de la începuturi până în secolul al VIII-lea, Editura Didactică și Pedagogică R.A., București; 
18. Sava A. V. (1937), Documente privitoare la Târgul și Ținutul Lăpuşnei, Fundația Regele Carol I, București;

19. Sava A. V. (1944), Documente privitoare la Târgul și Ținutul Orheiului, București;

20. Stefanelli T. V. (1915), Documente din vechiul ocol al Câmpulungului Moldovenesc, București/Viena/Lipsca;

21. Stoicescu N. (1971), Dicționar al marilor dregători din Țara Românească și Moldova în secolele XIV-XVII, Editura Enciclopedică Română, București;

22. Tocilescu Gr. G. (1931), 534 documente slavo-române din Țara Românească și Moldova privitoare la legăturile cu Ardealul 1346-1603, Cartea Românească, București;

23. Țopa D. (1928), Românismul în regiunea dintre Prut și Nistru din fosta Bucovină, Editura Casei Şcoalelor, București;

* * (1937), Abonații S.A.R. de telefonie. București și jud. Ilfov, Societatea Română Anonimă de Telefoane, București;

* * (1938), Abonații S.A.R. de telefonie. București și jud. Ilfov, Societatea Română Anonimă de Telefoane, București;

* * (1890-1900), Acte și documente relative la istoria renascerei României, vol. V-VII, Institutul de Arte Grafice Carol Göbl, București;

* * (1890-1914), Analele Parlamentare ale României, tom I-XVII, Imprimeria Națională, București;

* * (1925), Anuarul SOCEC al României Mari, vol. I-II, Editura SOCEC \& Co., Soc. Anon., București;

* * (1923), Dicționarul statistic al Basarabiei, Tiparul Societății Anonime „Glasul Țării”, Chișinău;

* * (1951-1956), Documente privind istoria României. A. Moldova (1384-1620), Editura Academiei, București;

${ }^{*}{ }^{*}$ (1990), Documente privind istoria României. A. Moldova. Veacurile XIV-XVII (1384-1620). Indicele numelor de locuri, Editura Academiei, București;

* * (1995), Documente privind istoria României. A. Moldova. Veacurile XIV-XVII (1384-1620). Indicele numelor de persoane, Editura Academiei, București;

* * (1951-1954), Documente privind istoria României. B. Țara Românească (1247-1625), Editura Academiei, București;

* * (1956), Documente privind istoria României. B. Țara Românească. Veacurile XIII-XVI. Indicele numelor de locuri, Editura Academiei, București;

** (1960), Documente privind istoria României. B. Țara Românească. Veacul XVII (1601-1625). Indicele numelor de locuri, Editura Academiei, București;

* * (1951-1954), Documente privind istoria României. C. Transilvania (1075-1350), Editura Academiei, București;

* * (1878-1938), Documente privitoare la istoria Românilor, vol I-XIX, (1518-1812), BucureștiCernăuți;

* * (1975-2006), Documenta Romaniae Historica. A. Moldova (1384-1646), vol. I-XXVIII, Editura Academiei, București;

** *(1965-2006), Documenta Romaniae Historica. B. Țara Românească (1247-1655), vol. I-XL, Editura Academiei, București;

* * * (1977-2014), Documenta Romaniae Historica. C. Transilvania (1351-1385), vol. X-XVI, Editura Academiei, București;

** * (1977), Documenta Romaniae Historica. D. Relații între Țările Române (1222-1456), vol. I, Editura Academiei, București;

* *(1888-1916), Harta topografică austriacă, ediția 1886-1916, scara 1:200000, Wien;

* * *(1893-1986), Hărțile topografice românești, edițiile 1893, 1917-1944, 1963-1973, 1996, București;

* * (1959), Lista abonaților telefonici, Ministerul Transporturilor și Telecomunicațiilor, București;

* * (1965), Lista abonaților la serviciul telefonic din București, Ministerul Transporturilor și Telecomunicațiilor, București;

* * (1966), Lista abonaților la serviciul telefonic. București, Ministerul Poștelor și Telecomunicațiilor, București; 
* * (1970), Lista abonaților la serviciul telefonic. București, Ministerul Poștelor și Telecomunicațiilor, București;

* * (2004), Listele electorale pentru alegerile locale, Primăriile unităţilor administrative din Țara

Oltului: municipiul Făgăraș, orașele Avrig, Victoria, comunele Arpaşul de Jos, Beclean, Boița,

Cârța, Cârțișoara, Comăna, Drăguș, Hârseni, Hoghiz, Lisa, Mândra, Părău, Porumbacul de Jos,

Racovița, Recea, Sâmbăta de Sus, Șercaia, Șinca, Șinca Nouă, Turnul Roșu, Ucea, Ungra, Viștea,

Voila;

* * (1975), Moldova în epoca feudalismului, vol. VII, părțile I-II, Editura Știința, Chișinău;

* * (1860-1861), Monitorulu Diaru Oficiale alu Țerei Romănesci, Bucuresci;

* * (1864-1877), Monitorul. Jurnal Oficial al Principatelor Române Unite, București;

* * *(1860), Monitorul Oficialu a Moldovei, Iași;

* * (1878-1941, 1990-2003), Monitorul Oficial, București;

* * (1931-2014), Recensămintele populației României din anii 1930, 1941, 1948, 1956, 1966, 1977,

1992, 2002, 2011, Institutul Central de Statistică/Direcția Centrală de Statistică/Institutul Național de Statistică, București;

* * (1946-1989), Scânteia, București;

* * (1991-2014), Tezaurul toponimic al României. Moldova, vol. I, părțile I-IV, Editura Academiei, București (părțile I-II)/Editura Universităţii „Alexandru Ioan Cuza”, Iași (părțile III-IV), vol. II, partea I, Editura Universității „Alexandru Ioan Cuza”, Iași;

http://forebears.io/surnames, February 15-April 29, 2016;

http://georgi.unixsol.org/diary/archive.php/2006-01-19, Mai 4, 2016;

http://nomerorg.com/allukraina/, August 9-September 2, 2016;

http://rompres.ro, http://agerpres.ro, October 27, 2008-March 19, 2016;

http://surnames.behindthename.com/, February 15-April 29, 2016;

http://tiraspol.telkniga.info/, August 9, 2016;

http://www.ancestry.com/, February 15-April 29, 2016;

http://www.cdep.ro, January 19, 2006-December 9, 2012;

http://www.cec.md, December 18, 2014;

http://www.locatemyname.com, February 15-April 29, 2016;

http://www.moldtelecom.md, August 9-14, 2016;

http://www.paginiaurii.ro, August 9-10, 2016; 
